\title{
Chapter 3 \\ Recruiting and Managing Labour for the Global Shipping Industry in China
}

\author{
Zhiwei Zhao
}

\section{Introduction}

China's economy has experienced dramatic growth in the last 30 years and in relation to seafaring labour supply many expected that Chinese seafarers would eventually come to dominate the world seafarers' labour market. In fact, although the number of Chinese seafarers in the international fleet has grown steadily since the 1990s, the increase has been slower than many international shipping industry commentators and academics predicted (BIMCO/ISF 1995; Li and Wonham 1999; Sharma 2002; Wu 2004; Wu et al. 2007; Zhao 2017).

This chapter aims to explain the shortfall in the anticipated export of China's seafarers by highlighting the reform and market-orientation of China's state-owned crewing agencies (SCAs). It raises questions concerning the interventions of the government and higher institutions in the SCAs and discusses how reforms have affected seafarers and seafarer labour export. It also systematically examines the employment and labour supply procedures of two SCAs and the impact of their strategies.

\section{The Idea of 'Going Global'}

Since the late 1990s, articles in trade papers for the maritime industry have reported that China's seafarer export would increase remarkably (Lloyd's Ship Manager 1999; Lloyd's List 2000, 2008, Zhao 2017). This conclusion is supported in the

\footnotetext{
Z. Zhao ( $\square)$

Dalian Maritime University, Dalian, China

University of Southern Denmark, Esbjerg, Denmark

e-mail: zhao@health.sdu.dk 
academic literature and BIMCO/ISF (1995), which estimated that China's seafarer export would increase to more than 89,000 by 2000 and to 104,000 by 2005 . Li and Wonham (1999) evaluated the report of BIMCO/ISF (1995) and argued that BIMCO/ISF had underestimated China's export of its seafarers in the 2000s, and that it could supplant the Philippines as the largest supplier of global seafaring labour (1999, 299).

Having evaluated the advantages (i.e. huge population of seafaring labour, good training infrastructure and the availability of alternative occupational opportunities) and the disadvantages (i.e. weak English and low occupational tenure) of China as a labour market, Sharma (2002) predicted that China would emerge as the new leader of the global seafaring labour market. Wu et al. (2006) also predicted the substantial increase of China's seafarer export after considering two issues. They deemed that the emergence of the hundreds of crewing agencies in the market would open new channels for Chinese seafarers to work on board foreign ships (Wu et al. 2007) and predicted that they would flood the world's seafarer labour market due to the attractions of working in foreign shipping companies, such as better pay (Wu 2004; Wu et al. 2006, 2007).

However, in 2000 and 2005, only 38,164 and 41,260 Chinese seafarers, respectively, worked in the global labour market, representing $42.8 \%$ and $39.7 \%$ of the numbers predicted by BIMCO/ISF (Bao and Liu 2008, p. 380). China has been ranked as the 4th/5th largest country in terms of maritime manpower supply ${ }^{1}$ in the world since the 2000s but represented approximately one fourth/fifth of the seafarer export from the Philippines both in the 1990s and the 2000s (Bao and Liu 2008; POEA 2018). In 2013, the Philippines, exported 367,166 seafarers which was more than three times higher than the 119,316 seafarers supplied by China (MSA 2014; POEA 2018). In 2017, 378,072 seafarers were exported by the Philippines and China dispatched 138,854 seafarers, representing $36.5 \%$ of the number of the Filipino seafarers working in the global labour market (MSA 2018; POEA 2018).

In consideration of this overestimation, a few researchers incline to a cautious analysis of Chinese seafarer export. Shen et al. (2005), Zhao (2000, 2002), and Tang et al. (2016) discuss the reform of China's seafarer labour market and analyze the potential constraints on the development of seafarer export, such as the development of the social security system, the English-speaking ability of Chinese seafarers and the complex dynamics of the world seafarers' labour market.

Whatever the assumptions and expectations, previous studies have focused on the export of Chinese seafarer labour while neglecting to analyze the ways in which crewing agencies operate and the extent to which crewing agencies have reformed into market-oriented economic entities that play a central role in providing labour to the global market. This gives rise to a number of elementary questions:

\footnotetext{
${ }^{1}$ BIMCO/ICS 2015 Manpower Report indicates that China is the largest labour supply country, meaning that China has the largest numbers of registered seafarers, rather than China supplies the largest number of seafarers to the global labour market.
} 
- To what extent can SCAs determine their own business strategy?

- To what extent are managers actively involved in improving and reforming management strategies?

- What specific management methods are applied by the crewing agencies?

- What are the consequent impacts on seafarers and on foreign manning businesses?

Answering these questions is critical when seeking to understand seafarer recruitment and employment in China and may contribute to a better understanding of the historic overestimates of China's seafarer export.

Given the lack of systematic evidence in the literature on these and related questions, the chapter seeks to explore the questions through an analysis of 54 semi-structured and 32 in-depth interviews conducted with 22 managers and 50 seafarers between 2008 and 2013 in two Chinese SCAs (hereinafter referred to as SA and IA; for more details please refer to Tables 3.1 and 3.2). The interview

Table 3.1 Interviews conducted between 2008 and $2013^{\mathrm{a}}$

\begin{tabular}{l|l|l}
\hline Years & 2008 and 2011 & 2012 to 2013 \\
\hline Interviews taken in SA & $\begin{array}{l}11 \text { interviews with managers and } \\
23 \text { with seafarers }\end{array}$ & $\begin{array}{l}\text { 4 interviews with managers and } \\
\text { 3 with seafarers }\end{array}$ \\
\hline $\begin{array}{l}\text { Interviews taken in IA } \\
\text { Number of interviews in } \\
\text { 27 with seafarers }\end{array}$ & 72 interviews & $\begin{array}{l}\text { 4 interviews with managers and } \\
\text { 3 with seafarers }\end{array}$ \\
\hline $\begin{array}{l}\text { Identity and post of inter- } \\
\text { viewees in SA }\end{array}$ & $\begin{array}{l}\text { Director, the Chair of the Trade Union, the Training manager, the } \\
\text { Human Research Management (HRM) manager, the Manning man- } \\
\text { ager, the Vice Director of the Head Office and the Director of the } \\
\text { parent shipping company (PSC); Seafarers of all ranks }\end{array}$ \\
\hline $\begin{array}{l}\text { Identity and post of inter- } \\
\text { viewees in IA }\end{array}$ & $\begin{array}{l}\text { Director, the HRM manager, the Manning manager, the Chair of the } \\
\text { trade union, the Business manager and the Training manager; Sea- } \\
\text { farers of all ranks }\end{array}$ \\
\hline & $\begin{array}{l}\text { A majority of the interviews lasted at least 1 hour and was voice- } \\
\text { recorded }\end{array}$
\end{tabular}

${ }^{\text {a }}$ The tables and figures in this chapter first appeared in Zhao et al. (2016), pp. 737-747

Table 3.2 Basic information about IA and SA

\begin{tabular}{l|l|l}
\hline Company name & IA & SA \\
\hline Category & ISCA & SSCA \\
\hline Year established & 1985 & 1995 \\
\hline Main client & Foreign shipping companies & PSC \\
\hline The number of ships manned in total in 2013 & 32 & 43 \\
\hline The number of foreign ships manned in 2013 & 32 & 9 \\
\hline The number of staff in 2013 & 20 & 58 \\
\hline The number of regularly employed seafarers in 2013 & 722 & 3380 \\
\hline The ranks of seafarers & Mainly officer seafarers & All ranks \\
\hline The number of freelance seafarers employed in 2013 & 387 & 0 \\
\hline
\end{tabular}

Sources: The two crew agencies 
questions were varied in accordance with the different positions of the interviewees. Each interview lasted at least one hour and was voice-recorded. The crewing agencies in the case studies have reformed to different degrees. They represent the largest examples of two types of Chinese crewing agency that dominate seafarer labour export. The study of the agencies allows an evaluation of the operations of the most important players in the Chinese seafaring labour market.

Before looking at the case studies, the chapter provides some macro level social and economic background by overviewing the reform of the Chinese economy, the seafarer labour market and ship crewing agencies.

\section{China's Economic Reform, Seafarer Labour Market Reform and Ship Crewing Agencies}

Before the economic reform of 1979, all political and economic activities in China were strictly planned and directly controlled by the Chinese government. Chinese enterprises were all state-owned. In 1979, in order to improve the economy, economic reform was introduced. The main focus of enterprise reform was the decentralization of power from the government. With the implementation of key reform measures, in theory, most of the state-owned enterprises (SOEs) were no longer supported by the government. They were supposed to operate independently and to be responsible for their own profits and losses. Non-state owned companies including privately-owned and foreign-backed enterprises made their first appearance in the late 1980s and have grown rapidly since the 1990s. They have contributed tremendously to the growth of China's economy (Garnaut et al. 2012).

The emergence and development of the Chinese seafaring labour market was the result of the economic reform. Before 1979, there was no labour market in China, as all workers were assigned by the government to certain work units (danwei) according to the government's plan. Since the 1990s, the evolution of the Chinese seafaring labour market has been driven by several main forces. Firstly, as a result of the economic reform the central government replaced the planned workers' assignment mechanism with a free, two-way selection system between employees and employers. This meant that workers could freely choose their employers, and employers were free to recruit and manage all employment issues associated with workers, without any intervention from senior government levels. Secondly, the reform of shipping companies, especially the emergence and development of privately-owned and foreign-backed companies, caused a huge demand for seafaring labour employed on fixed-term contracts. Thirdly, the implementation of the Labour Law in 1995 enabled SOEs which 'possessed' most seafaring labour to fire workers and to 'liberate' them from their traditional life-long employment status, replacing this with employment based on fixed-term contracts (Shen et al. 2005).

Hundreds of crewing agencies were set up to meet the demands of shipping companies as a result of these combined factors. However, according to the Labour 


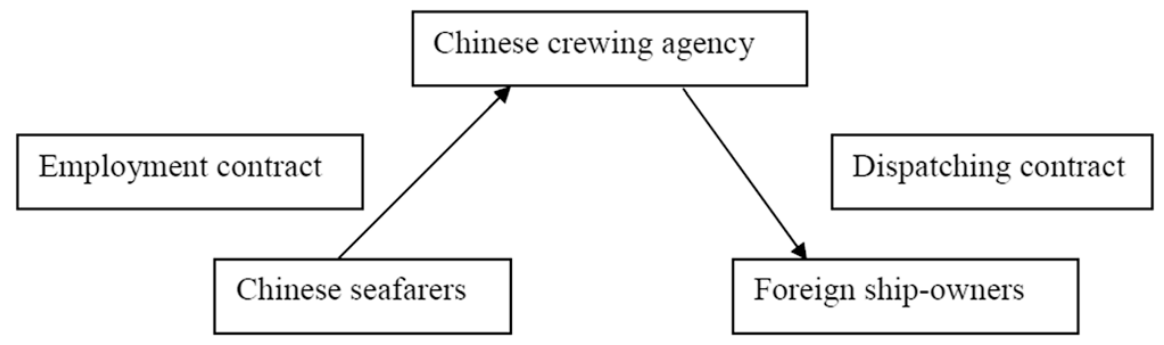

Fig. 3.1 The contract relationships in the foreign manning process

Laws of 1995 and the New Labour Contract Law of 2008, Chinese workers working overseas are not allowed to be directly employed by foreign employers but only through Chinese crewing agencies with foreign manning credentials. These serve to facilitate the participation of Chinese seafarers in the global labour market. In the crewing process, different sorts of contractual relations are involved (Fig. 3.1). Seafarers first sign an employment contract with a Chinese crewing agency which consequently becomes the buyer of the seafarers' labour and decides all employment issues, e.g. wages, working-hours, holidays, etc. These are based on the condition and standards of the Chinese labour market, and are lower than those of foreign shipping companies. Chinese seafarers rely directly on the Chinese agencies for employment. The crewing agency then signs a dispatching contract with the foreign ship-owner, the user of the seafarers' labour, who pays the agency for the labour. Chinese seafarers have no way of getting in touch with the foreign ship-owners whose ships they sail upon or to read this dispatching contract. They know nothing about the contents of the contract. Such a management mechanism sacrifices the interests of Chinese seafarers but protects China's shipping companies from foreign competition for labour resources.

SCAs have dominated the foreign manning business in China due to the support of the government in granting foreign manning certificates and financial subsidies. It has been reported that:

Between 1979 and 1998, COSCOMAN [COSCO's Manning Agency] employed 150,000 Chinese seafarers for foreign ship owners and operators, enjoying the lion's share of the market (60\%). MASES [a crewing agency owned by China Shipping] follows, during its ten years of business between 1988 and 1998, with a total supply of 40,000 seafarers, taking a market share of $16 \%$ (Zhao 2000, pp. 13-14).

Until the twenty-first century, the dominant position of the major SCAs was still evident. In 2012, the largest SCAs held a market share of around 65\%, which in 2017 increased to about $67 \%$. The remaining seafarers were supplied by small SCAs. Privately-owned crewing agencies played a minor role and to date only one foreignbacked crewing agency has established itself in China, making a minimal contribution to overall supply (interview with a maritime safety administrator (MSA) officer, September 4 2018). 
In the following section, the chapter focuses on the operations of the SCAs that dominate the crewing business in China in order to highlight some of the reasons why Chinese seafarers have not yet dominated the world's seafarer labour market, as previously predicted.

\section{Two Types of SCAs in China and the Two Agencies in the Case Studies}

SCAs in China can be roughly divided into two types. One is an independent SCA (ISCA), which is not affiliated to any shipping company. The other is a subsidiary crewing agency of a state-owned shipping company (known, for short, as subsidiary SCA (SSCA)).

The ISCA in the case study (hereinafter referred to as Independent Agency (IA)) was set up by the municipal government. IA has cooperated with foreign shipping companies since its establishment. It is one of the crewing agencies with the longest history and also one of the most influential agencies in China. IA is not affiliated to any shipping company, but supposedly operates independently, being responsible for its own profits and losses. SSCA is another type of SCA in China. Unlike ISCAs, which are established by the government, SSCAs are set up by state-owned shipping companies following the reform aimed at 'separating the management of the seafaring labour resource from the management of ships' (ren chuan fenli), by the Chinese central government in the 1990s. The SSCA in the case study (hereinafter referred to as Subsidiary Agency (SA), registered in 1995, is a constituent part of the largest operator in the entire Chinese shipping industry. It is a subsidiary crewing agency of its local branch shipping company (Fig. 3.2). Before registry, SA was the Seafarers' Resource Administration Department of its parent shipping company (PSC), responsible for crewing the company fleet as well as operating a crewing business that supplying seafarers to foreign shipping companies.

At this point, it is important to understand the constraints under which Chinese SCAs operate, then look at the support provided by government and the implications

$$
\text { SA's Head office (the largest operator in Chinese shipping industry) }
$$

Fig. 3.2 The structure of the relationship between SA and its parent shipping company and head office 
for foreign businesses. The two SCAs that are examined in the case studies represent the largest examples of the two types of Chinese crewing agencies that dominate seafarer labour export, i.e., SSCAs and ICSAs. The case studies allow us to see the operations of the most active and important players in the Chinese seafaring labour market.

\title{
The Control of the Higher Institutions
}

Despite registration as an independent company, at the time of the research, SA had little autonomy regarding its business operations. SA's clients and business cooperation details had to be approved by the parent shipping company (PSC) before starting the cooperation. To enjoy priority in selecting and employing high-quality seafarers, PSC defined the foremost task of SA as to offer the best crewing services to the PSC's ships, rather than enlarging the foreign manning business.

To maintain a high employment rate, the local government restricted SA in relation to sacking surplus labour (for the surplus rates please refer to Table 3.3). According to the human resources (HR) manager a vast majority of these seafarers were ratings. The Vice Director of the head office explained the reasons for employing surplus labour as follows:

\begin{abstract}
We need to maintain the stability of society by increasing employment opportunities. If surplus workers were fired, society would not be stable and the director of the PSC would be fired. It is the Party that leads the company. If you do so [fire the surplus workers], the leaders from the head office will instantly crack down on you. . .so you cannot ask SA to be marketoriented.
\end{abstract}

Concerning the specific HR management strategies, e.g. manning and promotion strategies and material support of seafarers etc., SA was also under the strict control of the PSC. Take the management of seafarers' material support for example. The gross input for the material support of seafarers and managers in SA was regulated by the head office of the PSC. When the wages of officer seafarers in the Chinese labour market increased rapidly in the mid-2000s, the wages of officer seafarers in SA did not increase much. The director of the PSC explained: 'We cannot improve

Table 3.3 The surplus rates of seafarers in some years

\begin{tabular}{l|l|l|l|l}
\hline Year & $\begin{array}{l}\text { Number of manned } \\
\text { ships }\end{array}$ & $\begin{array}{l}\text { Demand of } \\
\text { seafarers }\end{array}$ & $\begin{array}{l}\text { Number of seafarers on the } \\
\text { books }\end{array}$ & $\begin{array}{l}\text { Surplus rate } \\
\%\end{array}$ \\
\hline 1982 & 17 & 612 & 1619 & 62 \\
\hline 1995 & 47 & 1692 & 3082 & 45 \\
\hline 2006 & 62 & 2232 & 3003 & 25.7 \\
\hline 2013 & 43 & 1548 & 3380 & 45.8 \\
\hline
\end{tabular}

Source: SA's HRM Department

Note: With 24 seafarers on board each ship and a backup rate of 1.5, demand of seafarers equals to (number of manned ships) $* 24 * 1.5$ 
the wages of seafarers according to the situation in the labour market because the input for the wages is controlled by the head office'.

Following directives from the PSC the ratings in SA received much higher wages than the market rates in contrast to those of officer seafarers in SA. In the Chinese seafarer labour market freelance ratings were redundant, doing manual work for low wages; they were excluded from trade unions and easily exploited (Han 2008; Huang and Ning 2008; Zhang 2016). Providing ratings with high wages, permanent contracts and social insurance at the highest level was at odds with the position of ratings in the wider labour market. The HR manager explained the high material support for ratings as follows:

Over $70 \%$ of the registered ratings are over 45 years old. We need to take care of the elder comrades. It is the tradition of SOE that the working-class is the 'elder brother'. ${ }^{2}$ Therefore, although the wages of the ratings outside the state-owned enterprise are low, we still take care of our ratings, providing them with good wages and welfare. After all, we are all the working class.

The ratings in SA were very satisfied with their material support. However, some officer seafarers complained about management practice and considered it to be very unreasonable. A chief officer said:

The wages of ratings in SA are high. This violates the rule in the labour market. We officer seafarers should have been given higher wages because there is a shortage of us in the market and we need much longer training and face much greater costs than ratings... But now officer seafarers' wages in SA are lower than the rates in the domestic market. But ratings' wages are higher... This is very unreasonable.

As a result many officer seafarers who were able to find jobs for higher wages in other domestic agencies and shipping companies left SA. SA suffered from a loss of high quality seafarers, which resulted in the shrinking of the number of foreign ships manned by SA, from 24 in 2006 to nine in 2013 . Its profit in 2013 had decreased by $65 \%$ of the 2006 profit. In 2017, it manned 12 ships. Although the number of manned ships increased compared with 2013, because the ship-owners were smallscale, the profit levels remained similar.

Such control and intervention was not only restricted to SA. Although IA is presumed to operate independently and to be responsible for its profits and losses the case study demonstrates that there are interventions from its higher institutions (i.e. head office).

When IA was set up by the municipal government, the deputy mayor of the city at that time was elected as the first Chairman. IA merged with a SOE (which afterwards became IA's head office) in 1991 in accordance with the orders of the local government. Although IA still operated its business independently, the management

\footnotetext{
${ }^{2}$ In the planned economy, workers were the 'working class' and the 'masters of enterprises and the state'. Guided by this socialist ideology, workers were treated well and also as equally as possible, no matter of their skills or capability. Concerning the seafaring industry, there was no big difference in the wages of seafarers of different ranks. For instance, in 1988 a captains' wage was around 110-150 USD per month, while ratings could earn almost 90 USD.
} 
of IA was supervised by the head office for the local government. In terms of the distribution of profits, although the head office required IA to manage its own costs, including the seafarers' and managers' wages (which are set by the head office) they were required to hand over almost all net profits. These could not be lower than a certain amount set by the head office annually. In order to fulfil these demands IA was unable to pay officer seafarers competitive wages. The Manning manager said: 'The wage of our officers is not high: it is equal to or lower than the average rate in the domestic market'. The Director of IA explained:

We also want to increase seafarers' wages. However, the head office will not allow this. If we were to give more money to seafarers, the agency's profits would fall. In this case, how can we reach the required standard [set up by the head office]? In fact, the managers of the head office do not consider the condition of the labour market or adjust the requirements accordingly... the head office does not allow us to become independent, as it would lose the profit that we submit. So we are stuck here.

The independence of IA was still quite circumscribed by the relationship with the head office and this suggests that IA was not really independent in terms of the control that it had over its profits. This control resulted in the low wages of seafarers and a mass of officers left the agency for land-based jobs and jobs in other domestic shipping companies with higher wages. Ultimately the export of seafaring labour stagnated.

In addition to these controls and interventions, the case studies showed that SCAs received various kinds of support from their higher institutions, which resulted in managers being reluctant to carry out any reforms. This was particularly evident when looking at the case of SA.

\section{The Support of Higher Institutions}

Despite being registered as an independent company, SA still acted like an internal department of the parent shipping company (PSC). All costs of the agency were met by the PSC. Unlike IA, when SA made losses, the PSC compensated for it. Reliant on the PSC, SA did not have to be responsible for its profits and losses. The director of the PSC explained the relationship between the PSC and SA:

The agency was registered as a company by the PSC, which means one of our departments is qualified to do business with other companies. To other companies, the agency is a company; but for the PSC, it is our department, as everything of the agency is from us.

With such support, managers in SA were not incentivized to carry out any reforms. While ignoring reforms or achieving low profits will not cause the managers problems, implementing reforms (e.g. the advancement of management strategies and improvement of market-orientation) could be complicated, risky and troublesome. The president of the Trade Union explained this in the following way:

Everyone knows the problems of the management but no one talks about them. The reason is like this: if nobody changes the management, when problems occur, no one will be blamed. 
This is because the problems have existed for 20 years, and have not been caused by any of the current managers. But if anyone reformed any strategy, he would take the full responsibility and be blamed for any consequences. Therefore, it is safer to keep the current strategies rather than reform them.

Consequently, the managers would rather choose to stay safe than implement a potentially risky reform that might damage their personal interests. This in turn resulted in management strategies in SA lacking a market orientation in keeping with the economic reform.

\section{Lack of Reform of Management Strategies in SA}

To date, crew management and promotion policies are still based on a strategy of 'fixed ship, fixed crew' (FSFC) which can be traced back to the beginning of the 1990s. This requires seafarers assigned to a ship to work there consistently for as long as the vessel is in operation. Seafarers who have not been assigned to a particular ship get few working opportunities under this system. A HR manager said: 'In the agency, a group of seafarers are so tired because they are always called to work on board ship, while the rest have no opportunity at all'.

Lack of reform by management also resulted in the slow promotion of seafarers. The regulations implemented in 1991 required captains and manning managers to take full responsibility for any mistakes on board ships. Since newly promoted seafarers lack experience, captains and manning managers were reported to block seafarers' promotion in order to avoid potential consequences and punishment. The manning manager said:

If there is an accident, the director of the parent shipping company or the Head Office will first ask the manning manager whether the dispatched seafarers have worked in the position before or whether the seafarers have adequate experience. If not, the leaders will ask the managers why they dispatched those new, inexperienced seafarers. There have been some bad examples when manning manager have faced serious consequences because they dispatched newly promoted seafarers. We have now learned to avoid these mistakes. This is the problem with the institutional system - seafarers' promotion is delayed.

Concerning the management of seafarers' training, managers and seafarers complained that training opportunities were not systematically planned or distributed among seafarers. As a result, some seafarers were trained repeatedly in SA while others hardly got any training. The President of Trade Union commented on the management of training:

When there is a training opportunity, in many cases, it is the manning managers who look for training candidates, not based on any training schedule but randomly... Because of the lack of any plan, some seafarers undertake the same training several times, while others are not trained at all.

A rating who was related to a crewing manager said: 
Sometimes, when I am on leave, the manning manager calls me to take some training. I had already done those modules several times and I don't want to do them again. But considering my relationship with the manning manager and considering that he consistently gives me good working opportunities, I cannot refuse him. So I take the lessons.

The analysis shows that the reform of the management strategies was limited in SA. Seafarers experienced slow promotion, limited working opportunities and poor regulation of training. This contributed to the loss of high quality seafarers and hence limited the potential to increase seafarer export.

\section{Conclusion}

Despite 30 years of economic reform, the volume of Chinese seafarer export has grown much more slowly between 1990 and 2015 than was predicted by the international shipping industry and some academics (Li and Wonham 1999; Sharma 2002; Wu 2004; Wu et al. 2007; Zhao 2017). Though previous research mentioned some obstacles to China's seafarer export, it was taken for granted that the problems would be solved with the expansion of the economic reform and the emergence of hundreds of crewing agencies in China. The complexity of the problems and the capacity of crewing agencies to man foreign ships was not considered however. This chapter reveals the extent to which inertia prevails in the operation of Chinese manning agencies and the ways in which conservative strategies for survival block the paths to reform and the opening up of the labour market.

A few western social scientists have looked into the reform of Chinese SOEs of land-based industries. They argue that despite the dramatic growth of the Chinese economy, the reform of China's SOEs remains limited in terms of managerial autonomy due to the government restrictions (Bodmer 2002; Gu 2001; Zhang and Rasiah 2014), government's support of the SOEs (Lewis 2003; Taylor 2005; Wei et al. 2015) and the maintenance of the traditional administrative ties within the SOE system, which give parent companies strict control over their subsidiaries (Cui and Jiang 2011; Xiao et al. 2006).

So far, the SCAs dominate the foreign manning business. However, the case studies of SA and IA, two of the most influential foreign manning agencies in China, demonstrate that the SCAs may not be as reformed or market-oriented as assumed (Li and Wonham 1999; Sharma 2002; Wu 2004; Wu et al. 2007; Zhao 2017). Although the agencies were registered as independent enterprises, they received various forms of support and constraints from governmental departments and head offices. Their autonomy regarding business operations was limited and flexibility in adjusting management strategies in response to labour market conditions was constrained producing management strategies which lacked market orientation. As a result of these problems, companies faced the resignation of officers and shortfalls in high quality seafarers which consequently constrained the volume of seafarers 'exported' to the global labour market. 
It seems that although economic reforms demand that the state relinquishes the control and central planning of the seafarer labour market it has nevertheless retained these by applying different control mechanisms to crewing agencies. The research underpinning this chapter indicates that that the market remains heavily governmentcontrolled. The contradictions underlying the policy reforms explain the failure of Chinese seafarers to dominate the global market as anticipated.

To improve the competitiveness of the foreign manning business and the market orientation of Chinese SCAs, it may be necessary for the state to further relax its control over the Chinese seafarer labour market. This can be achieved by granting more autonomy and responsibility to crewing agencies enabling managers to act more effectively. This research suggests that if allowed to change then some of them are prepared for such a transition. However, there are no present indications that such changes are likely to occur.

\section{References}

Bao, J., and Z. Liu. 2008. Seafarers' Education and Training System in China. In Shenzhen International Maritime Forum. Shenzhen: People Communication Press.

BIMCO/ISF. 1995. The Worldwide Demand for and Supply of Seafarers Manpower Update: Main Report. The University of Warwick Institute for Employment Research.

Bodmer, F. 2002. The Effect of Reforms on Employment Flexibility in Chinese SOEs, 1980-1994. Economic of Transition 10 (3): 637-658.

Cui, L., and F. Jiang. 2011. State Ownership Effect on Firms' FDI Ownership Decisions Under Institutional Pressure: A Study of Chinese Outward-Investing Firms. Journal of International Business Studies 43: 264-284.

Garnaut, R., L. Song, Y. Yao, and X. Wang. 2012. Private Enterprise in China. Australia: ANUE Press.

Gu, E.X. 2001. Beyond the Property Right Approach: Welfare Policy and the Reform of StateOwned Enterprises in China. Development and Change 32 (1): 129-150.

Han, J. 2008. Providing Personnel Security for the Sustainable Development of China's Shipping Industry. In Shenzhen International Maritime Forum. Shenzhen: People Communication Press.

Huang, Z., and W. Ning. 2008. Study on the Necessity of Publishing Standard Contract and Auditing Regulations for Chinese Seafarers Working on Board Foreign Ships. In Shenzhen International Maritime Forum. Shenzhen: People Communication Press.

Lewis, P. 2003. New China-Old Ways? Employee Relations 25 (1): 42-60.

Li, K.X., and J. Wonham. 1999. Who Mans the World Fleet? A Follow-Up to the BIMCO/ISF Manpower Survey. Maritime Policy \& Management 26 (3): 295-303.

Lloyd's List. 2000. Chinese crew set to increase. October 23.

2008. Shanghai's surge continues apace. March 14.

Lloyd's Ship Manager. 1999. Barrier to Chinese seafarers breaking down.

MSA (Maritime Safety Administration). 2014. Statistical Information of Seafarers. Available at: http://xxgk.mot.gov.cn/jigou/haishi/201406/t20140626_2979758.html

- 2018. Statistical Information of Seafarers. Available at: http://www.rmjtxw.com/news/ yaowen/41068.html

POEA (Philippine Overseas Employment Administration) 2018. Deployed Overseas Filipino Workers - By Type of Hiring, 2006-2018 (1st SEM). Available at: http://www.poea.gov.ph/ ofwstat/compendium/deployment\%202006-2018S1.pdf. 
Sharma, K.K. 2002. The Sea-Going Labour Market in the People's Republic of China and its Future. In Shipping in China, ed. T.W. Lee. London: Ashgate Publishing.

Shen, G., M. Zhao, L. Li, and J. Song. 2005. Chinese Seafarer. Shanghai: Shanghai University Press.

Tang, L., M.O.S. Llangco, and Z. Zhao. 2016. Transformations and Continuities of Issues Related to Chinese Participation in the Global Seafarers' Labour Market. Maritime Policy and Management 43 (3): 344-355. https://doi.org/10.1080/03088839.2015.1043751.

Taylor, R. 2005. China's Human Resource Management Strategies: The Role Enterprises and Government. Asian Business \& Management 4 (1): 5-21.

Wei, T., J. Clegg, and L. Ma. 2015. The Conscious and Unconscious Facilitating Role of the Chinese Government in Shaping the Internationalization of Chinese MNCs. International Business Review 24 (2): 331-343.

Wu, B. 2004. Participation in the Global Labour Market: Experience and Responses of Chinese Seafarers. Maritime Policy and Management 31 (1): 69-72.

Wu, B., K.H. Lai, and T.E. Cheng. 2006. Emergence of 'New Professionalism' Among Chinese Seafarers: Empirical Evidence and Policy Implications. Maritime Policy \& Management 33 (1): $35-48$.

Wu, B., G. Shen, and L. Li. 2007. The Transformation of the Chinese Labour Market for Seafarers. Seafarers International Research Centre: Cardiff University. ISBN: 1-900174-33-2.

Xiao, Y., J. Morris, J. Hassard, and J. Sheehan. 2006. Downsizing The Danwei: Chinese StateEnterprise Reform and the Surplus Labour Question. The International Journal of Human Resource Management 17 (8): 1441-1455.

Zhang, M., and R. Rasiah. 2014. Institutional Change and State-Owned Enterprises in China's Urban Housing Market. Habitat International 41: 58-68.

Zhang, P. 2016. Seafarers' Rights in China: Restructuring in Legislation and Practice Under the Maritime Labour Convention 2006. In Seafarers Rights in China: Restructuring in Legislation and Practice Under the Maritime Labour Convention 2006. London: Routledge.

Zhao, M. 2000. Chinese Seafarers: Value for Money or Cheap Labour? In Maritime Review, 11-15. London: Pacific Press.

2002. The Consequences of China's Socialist Market Economy for Seafarers. Work, Employment and Society 16 (1): 171-183.

Zhao, T. 2017. Chinese Crewing Ready for Global Shipping, Capital Link Forum, November 1, Athens. Available at: http://forums.capitallink.com/csr/2017athens/ppt/zhao.pdf

Zhao, Z., R.J. Jepsen, and L. Tang. 2016. The Reform of Chinese State-Owned Ship Crewing Agencies and Implications for China's Seafaring LABOUR Export. Maritime Policy \& Management 43 (6): 737-747. https://doi.org/10.1080/03088839.2016.1169450.

Open Access This chapter is licensed under the terms of the Creative Commons Attribution 4.0 International License (http://creativecommons.org/licenses/by/4.0/), which permits use, sharing, adaptation, distribution and reproduction in any medium or format, as long as you give appropriate credit to the original author(s) and the source, provide a link to the Creative Commons licence and indicate if changes were made.

The images or other third party material in this chapter are included in the chapter's Creative Commons licence, unless indicated otherwise in a credit line to the material. If material is not included in the chapter's Creative Commons licence and your intended use is not permitted by statutory regulation or exceeds the permitted use, you will need to obtain permission directly from the copyright holder.

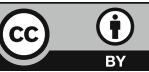

